\title{
Smoking among male medical sciences students in Semnan, Islamic Republic of Iran
}

\author{
A.A. Nazary, ${ }^{1}$ F. Ahmadi, ${ }^{2}$ M. Vaismoradi, ${ }^{3}$ K. Kaviani, ${ }^{4}$ M. Arezomandi ${ }^{4}$ and S. Faghihzadeh ${ }^{5}$
}

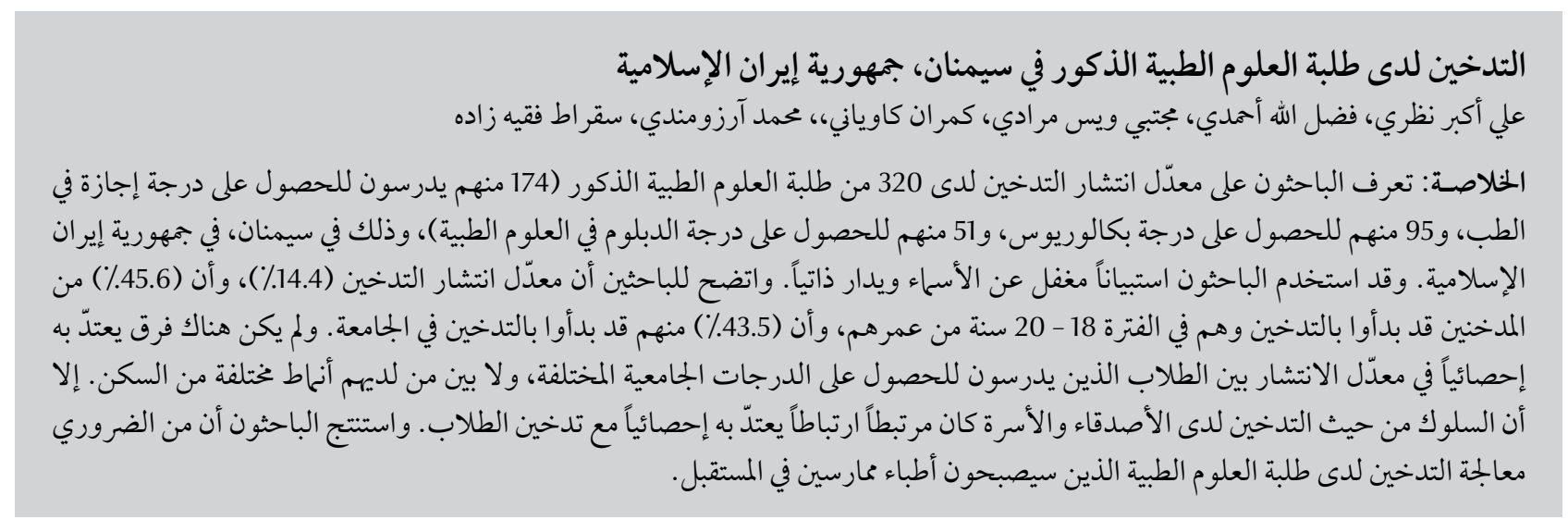

ABSTRACT We determined the prevalence of smoking among 320 male medical sciences students (174 studying for a medical degree, 95 a bachelor degree and 51 a associate degree) in Semnan, Islamic Republic of Iran. A self-administrated, anonymous questionnaire was used. The prevalence of smoking was $14.4 \% ; 45.6 \%$ of the smokers started smoking between the ages of 18 and 20 years, $43.5 \%$ starting at university. There was no significant difference in the prevalence between students undertaking different college degrees and also those having different types of accommodation. However the smoking behaviour of friends and family was significantly correlated with smoking in the students. Smoking amongst medical sciences students, who will become the health professionals of the future, needs to be addressed.

\section{Le tabagisme chez les étudiants en sciences médicales de sexe masculin à Semnan (République islamique d'Iran)}

RÉSUMÉ Nous avons déterminé la prévalence du tabagisme chez 320 étudiants en sciences médicales de sexe masculin (dont 174 inscrits en cursus de médecine, 95 en licence et 51 inscrits en cursus court de deux ans) à Semnan, en République islamique d'Iran. Nous avons utilisé un auto-questionnaire anonyme. La prévalence du tabagisme était de 14,4 \% 45,6\% des fumeurs avaient commencé à fumer entre 18 et 20 ans, tandis qu'ils étaient 43,5 \% à avoir commencé à l'université. En termes de prévalence, aucune différence significative n'a été relevée entre les différents types d'études, ni entre les différents types de logement. Cependant, une étroite corrélation a été observée entre le comportement des amis et de la famille en matière de tabagisme et celui des étudiants. Le problème du tabagisme chez les étudiants en sciences médicales, qui deviendront des professionnels de la santé, doit être traité.

'Nursing Faculty, Islamic Azad University of Dezfool, Khuzestan, Islamic Republic of Iran (Correspondence to A.A. Nazary: Nazary_ali@yahoo. com).

${ }^{2}$ Nursing Department; ${ }^{5}$ Biostatistics Department, Faculty of Medical Sciences, Tarbiat Modares University, Tehran, Islamic Republic of Iran.

${ }^{3}$ Faculty of Nursing and Midwifery, Tehran Univeristiy of Medical Sciences, Tehran, Islamic Republic of Iran.

${ }^{4}$ Semnan University of Medical Sciences, Semnan, Islamic Republic of Iran.

Received: 16/07/07; accepted: 22/10/07 


\section{Introduction}

Smoking is a major health hazard as smokers have more diseases and die earlier than nonsmokers [1]. At the same time, there has been an alarming increase in smoking among young adults since the early 1990s [2]. In 2003 Johnston et al. reported that the 30-day smoking prevalence among college students increased from $23 \%$ to $31 \%$ between 1991 and 1999, before levelling off at about $27 \%$ [3]. Daily smoking rose during the same period by $40 \%$ from $14 \%$ to $19 \%$, and now is about $16 \%$ [3]. As a result, the age range 18-24 years now has the highest prevalence of smoking in the United States of America [4]. These rates for young adults have serious public health implications [5].

The prevalence of smoking among health care providers has been shown to vary widely [6]. In a series of studies undertaken by the International Union Against Tuberculosis and Lung Disease (IUATLD) along with World Health Organization (WHO), 9000 medical students from 42 countries were surveyed $[7,8]$. Central Asian countries were not included in these surveys; however some data became available from a separate study in Tashkent [9]. In the majority of these studies, it was shown that Asian students smoked less than European students [10,11].

For many adolescents, college marks the beginning of an important transition to emerging adulthood [12]. We identified only 1 study that examined college smoking using a prospective design. Wetter et al. in 2004 examined changes in smoking among a sample of American college students over a period of 4 years, and found considerable heterogeneity in the longitudinal progression of smoking; smoking increased for some students but decreased or remained stable for others [13]. The WHO has stated clearly that health professionals can have a significant influence (positive or negative) on the smoking habits of a community
[14]. It has been observed that doctors who smoke tend to be more permissive, are less inclined to advise their patients against tobacco use, and adopt a passive attitude towards smoking [15]. This happens even though health care professionals are usually more aware of the adverse health consequences of cigarette smoking compared to the general population [16]. Medical sciences students, such as doctors, nurses, pharmacists or health administrators, as future health care professionals, can play a central role in preventive programmes due to their appropriate knowledge and attitudes [17]. The college years are a formative period when many young adults experiment with newideas and behaviours that can have an impact on the rest of their lives. Therefore it is important that medical schools use the opportunity to reach students during their undergraduate years and address the subject of smoking [18].

To gain a better understanding of behavioural predictors of smoking status and to promote anti-smoking measures for future health care professionals, we believe that it is necessary to study the smoking behaviour of medical sciences students in our country. Therefore we aimed to determine the prevalence of smoking among male medical sciences university students in Semnan, Islamic Republic of Iran and to examine some sociodemographic factors that influence them to smoke. Because smoking in Iranian women is not yet very common, we restricted our sample to male students.

\section{Methods}

\section{Design and subjects}

We conducted a cross-sectional descriptive study in Semnan Medical Sciences University which was selected randomly from all the Iranian medical sciences universities (there is just 1 medical sciences university in each state in the Islamic Republic of Iran).
The investigation of the prevalence of cigarette smoking in all medical sciences universities in the country (41 universities) has been considered a priority in recent years and Semnan was one of the first universities to be studied.

The participants comprised all male students studying various medical sciences: medicine, nursing, speech therapy, physiotherapy, radiology, laboratory sciences, medical records, anesthesiology, and operating room who attended the university. There were a total of 390 students eligible for inclusion, 332 of whom responded while 58 refused to participate, giving a response rate of $85 \%$. In addition, 12 respondents were excluded because their answers regarding their demographic and smoking status were incomplete or contradictory. Therefore a total of 320 participants (174 studying for a medical degree, 95 a bachelor degree, and 51 an associate degree) were included in the analyses.

\section{Data collection instrument}

An anonymous, self-administrated, closed-ended, structured questionnaire was used for the study. The questions asked are shown in Table 1. We could not find a previously developed questionnaire appropriate for this study, and hence we developed a new one in Farsi. The design of the questionnaire was guided by the experience gained in recent years by researchers and expert consultation and was also based on data from the current literature (especially articles on smoking habits among sixthyear medical sciences students in Spain by Mas et al. [19]).

As regards definitions: non-smoker was a person who had never smoked cigarettes; current smoker was person who currently actively smoked cigarettes, both every-day and occasional smokers; former smoker was a person who had tried 1 or 2 cigarettes or had smoked regularly but did not smoke at the time of data gathering. Because certain important predisposing factors 


\begin{tabular}{l}
\hline Table 1 Questions included in the questionnaire \\
\hline First section \\
Age \\
Faculty \\
Accommodation \\
Marital status \\
Have you ever smoked? If your answer to this question is no, you need not answer \\
any more questions \\
Second section \\
Do you currently smoke? \\
What age were you when you started smoking? \\
How many cigarettes do you or did you smoke a day? \\
Have you smoked or did you smoke for 6 months or more? \\
Did you start to smoke after you entered the Medical Sciences University? \\
Do you want to stop smoking? \\
Have you ever made a serious attempt to stop smoking? \\
Why did you stop smoking? \\
If you failed to quit, what do you think was the reason for this failure? \\
If you are not a current smoker, how many months have passed since you last \\
smoked? \\
How much do you pay for cigarettes per day? \\
Which of these cigarettes do you prefer: Iranian or foreign cigarette? \\
Are there any cigarette smokers in your family? \\
Do you have any close friend or roommate that smokes cigarette? \\
Do you feel any psychophysical dependency on cigarette smoking? \\
\hline
\end{tabular}

for cigarette smoking among college students have been reported (e.g. having a relative who smoked or living on campus rather than at home) [20-22] and we wished to compare our results with international studies, some these factors were included in the study.

There were 3 phases in the development of the questionnaire.

Phase 1: The questionnaire was designed in 2 parts to collect data from students. It comprised 20 questions, coded and grouped into 2 subsections: the first comprised questions concerning demographic data; the second section dealt with smoking habits. A pilot study was done on 20 medical sciences in order to assess the appropriateness of the questionnaire in terms of clarity, comprehensiveness and difficulty. While the students had no problems in responding to the questions, they did suggest some modifications for clarity.

Phase 2: The questionnaire was given to 10 medical sciences faculty members to examine the content validity. This
Medical Sciences. To protect the privacy of participants and to obtain as frank answers as possible, it was explained that no member of staff at the university would have access to responses and that the questionnaire would be collected in sealed envelopes. It was also explained that participation was voluntary and that not participating would not have any repercussions. Students who agreed to participate in the study signed a written consent form, completed the questionnaire and handed it to the researcher in the sealed envelope.

\section{Data analysis}

SPSS for Windows, version 13.0, was used for data analysis. Descriptive statistics were used to analyse all study variables. The data were summarized using frequencies and percentages. Sociodemographic characteristics of the student by smoking status were reported as odds ratios (OR) and confidence intervals (CI).

process led to some further modifications in questions and all of the questions were considered valid.

Phase 3: The questionnaire was finalized. It included an introductory cover letter giving information about the aims of the study and informing the student that they could withdraw from the study without being penalized.

\section{Ethical considerations and data collection}

Data were collected during September and October 2006.

The survey was approved by the ethics committee of Semnan University of

\section{Results}

Among the 320 respondents included in the analysis, the mean age was: medical degree 24.7 years, bachelor degree 20.8 years and associate degree 20.4 years. The mean age and smoking status of the students by college degree are shown in Table 2.

Most of the students (56.2\%) were nonsmokers while $14.4 \%$ currently smoked and $29.4 \%$ were former smokers (Table 3). Of the current smokers, $45.6 \%$ started smoking between 18 and 20 years

\begin{tabular}{|c|c|c|c|c|c|c|}
\hline \multicolumn{7}{|c|}{$\begin{array}{l}\text { Table } 2 \text { Mean age, range and standard deviation (SD) of students by smoking } \\
\text { status and college degree }\end{array}$} \\
\hline \multirow[t]{2}{*}{ College degree } & \multicolumn{3}{|c|}{ Smoker } & \multicolumn{3}{|c|}{ Nonsmoker } \\
\hline & $\begin{array}{l}\text { Mean age } \\
\text { (years) }\end{array}$ & SD & Range & $\begin{array}{l}\text { Mean age } \\
\text { (years) }\end{array}$ & SD & Range \\
\hline Doctor & 25.8 & 4.36 & $18-35$ & 24.5 & 4.89 & $18-37$ \\
\hline Bachelor & 21.7 & 2.25 & $18-26$ & 20.7 & 4.09 & $18-37$ \\
\hline Associate degree & 22.3 & 3.7 & $18-29$ & 20.0 & 1.81 & $18-26$ \\
\hline
\end{tabular}


and $43.5 \%$ started smoking in university. Cigarette consumption was not high, with the majority (67.4\%) of smoker students smoking $\leq 3$ cigarettes/day.

The association of sociodemographic characteristics with smoking status is shown in Table 4. Evaluation of correlates of smoking for multivariate analysis was based on a logistic regression analysis. All of the respondents were included. There was no significant difference in the prevalence of smoking among the students undertaking different college degree and in different accommodation conditions $(P>0.1)$. However, the smoking behaviour of family or friends was correlated with smoking in the students $(\mathrm{OR}=11.20$; $\mathrm{CI}=6.22-19.90)(P<0.05)$

\section{Discussion}

The prevalence of smoking among medical science students in our study

\begin{tabular}{|c|c|c|}
\hline Features & No. & $\%$ \\
\hline \multicolumn{3}{|l|}{$\begin{array}{l}\text { Smoking status } \\
(n=320)\end{array}$} \\
\hline Nonsmoker & 180 & 56.2 \\
\hline Current smoker & 46 & 14.4 \\
\hline Former smoker & 94 & 29.4 \\
\hline \multicolumn{3}{|l|}{$\begin{array}{l}\text { Age at starting } \\
\text { smoking (years) } \\
(n=46)\end{array}$} \\
\hline$<15$ & 9 & 19.6 \\
\hline 15-17 & 5 & 10.9 \\
\hline $18-20$ & 21 & 45.6 \\
\hline $21-23$ & 6 & 13.0 \\
\hline$\geq 24$ & 5 & 10.9 \\
\hline \multicolumn{3}{|l|}{$\begin{array}{l}\text { Level of first starting } \\
\text { cigarettes }(n=46)\end{array}$} \\
\hline Primary school & 4 & 8.7 \\
\hline Guidance school & 4 & 8.7 \\
\hline High school & 16 & 34.8 \\
\hline Military service & 2 & 4.3 \\
\hline University & 20 & 43.5 \\
\hline \multicolumn{3}{|l|}{$\begin{array}{l}\text { Mean cigarette } \\
\text { consumption/day } \\
(n=46)\end{array}$} \\
\hline$\leq 3$ & 31 & 67.4 \\
\hline $4-9$ & 10 & 21.7 \\
\hline 10-19 & 3 & 6.5 \\
\hline$\geq 20$ & 2 & 4.3 \\
\hline
\end{tabular}

\begin{tabular}{|c|c|c|c|c|}
\hline \multicolumn{5}{|c|}{$\begin{array}{l}\text { Table } 4 \text { Sociodemographic characteristics of the students by smoking status and } \\
\text { estimates of odds ratios with } 95 \% \text { confidence intervals of odds for smoking }\end{array}$} \\
\hline Variable & No. & $\%$ & $\begin{array}{l}\text { Odds } \\
\text { ratio }\end{array}$ & $\begin{array}{c}95 \% \\
\text { confidence interval }\end{array}$ \\
\hline \multicolumn{5}{|l|}{ College degree } \\
\hline Associate degree & $8 / 51$ & 15.7 & 1 & \\
\hline Bachelor & $14 / 95$ & 14.7 & 0.93 & $0.36-2.39$ \\
\hline $\begin{array}{l}\text { Doctor } \\
\text { Smoking behaviour } \\
\text { in family/friend }{ }^{a}\end{array}$ & $24 / 174$ & 13.8 & 0.86 & $0.36-2.03$ \\
\hline Father & $21 / 140$ & 15.0 & 1 & \\
\hline Friend & $93 / 140$ & 66.4 & 11.21 & $6.22-19.90^{* *}$ \\
\hline \multicolumn{5}{|l|}{ Accommodation } \\
\hline $\begin{array}{l}\text { At home with } \\
\text { parents }\end{array}$ & $9 / 58$ & 15.5 & 1 & \\
\hline At home alone & $5 / 62$ & 8.1 & 0.48 & $0.15-1.50$ \\
\hline In a dormitory & $32 / 200$ & 16.0 & 1.03 & $0.46-2.29$ \\
\hline
\end{tabular}

${ }^{a}$ Current and former smokers.

**Significant at $P<001$.

was $14.4 \%$. Studies conducted on nursing students in other countries have shown that the percentage of cigarette smokers ranged from $12.9 \%$ to $24 \%$ [23]. In a study of nursing students in Turkey the proportion of cigarette smokers ranged from $25.8 \%$ to $44.2 \%$ [24]. Hadad and Malak in Jordan found the prevalence to be $28.6 \%$ among male and female university students [25]. A WHO report in 2001 gave the smoking prevalence among Iranian adults as $24 \%$ in males [26]. Our rate was lower than these. On the other hand, in 1999 WHO indicated that smoking rates in all developing countries were approaching $48 \%$ among males and $7 \%$ among females [27]. The prevalence of smoking in the Islamic of Iran is low, not only for medical science university students but also for the general population compared to other countries. The low prevalence of smoking in our country may be due to socioeconomic and cultural characteristics, and the religious beliefs of Iranian families that discourage smoking among youth and women.

In our study most of the current smokers had started smoking at age 18-20 years, correspondind with the finding that most started smoking at university. Similarly, national studies on smoking behaviour in Thailand in 1998 and 2001 reported $60 \%$ of all smokers began smoking between the ages of 15 and 19 years [28]. Another trend that has been noted in this group is that $11 \%$ of college smokers had their first cigarette at or after the age of 19 years [29]. The late and extended onset of tobacco use presents another challenge for tobacco control. Further longitudinal studies are warranted to determine the likelihood of these late onset smokers progressing to higher levels of smoking, in order to develop effective tobacco control among college students [30].

The mean number of cigarettes smoked was $\leq 3$ per day, which is lower than the rate reported in a study in Spain among medical students: mean 10.54 (SD 7.89) per day [19].

In our study, there was no significant difference in the prevalence of smoking among the students undertaking different college degrees. A study in the United States in 2003 showed that significantly fewer medical students (3.3\%) smoked compared to nursing students (13.5\%) [23].

Our results showed that smoking behaviour in friends and family was 
correlated with smoking in the students, but there was no relationship in accommodation status of students. In a study in Turkey, students who lived with their friends were more likely to smoke than those who lived with their families [20]. Another study in Turkey also found a significant statistical association between student smoking status and place of residence, with more smokers rooming with a friend. In addition, a significant association was found between student smoking and family members smoking. There was a higher rate of smoking among students who had smokers in their families [21].

Similarly, Yazici and Özbay found that students started smoking under the influence of their friends [22]. University students living away from home use their friends as a means of social support. Young adults also desire to belong to and be accepted by a group, and to engage in the behaviours of that group. This may be why students living with their friends had a higher rate of smoking. Having a family member who smoked also influenced students' smoking status [22]. Other studies conducted both in Turkey and in other countries have shown that the smoking habits of family members have a meaningful effect on student cigarette-smoking behaviour [31]. Cigarette smoking is influenced by social learning and behavioural modelling. Young people will use their elders and family members as models for their smoking habits [32].

There were 2 key limitations to this study. The sample was taken from 1 university in a single Iranian state and therefore the findings are not necessarily representative of medical sciences students elsewhere in the country. The second limitation is that the data were based on a self-reported questionnaire and were thus subject to bias. Although the survey was anonymous, medical sciences students may be more sensitized to the issue of smoking and health and those who smoke might under-report or deny their habit more frequently than the general population. This study focused only on cigarette smoking among male students. Investigating other types of smoking, such as the water pipe, and smoking among female students are avenues for future research.

\section{Conclusion}

Smoking amongst medical sciences students who will become the health professionals of the future is a problem as practitioners can play an important role in assisting patients to stop smoking with their unique positions in the community. However, health professionals who smoke are significantly less likely to determine the smoking status of their patients and less likely to provide antismoking educational materials to their patients [15]. Therefore efforts to curb smoking among today's medical sciences students is a preventive approach to the problem of smoking among tomorrow's health care professionals. Even though the prevalence of smoking among our student sample was low, it nonetheless warrants attention particularly given the influence they may have in their future professional life.

\section{References}

1. Wald NJ, Hackshaw AK. Cigarette smoking: an epidemiological overview. British medical bulletin, 1996, 52:3-11.

2. Lantz PM. Smoking on the rise among young adults. Implications for research and policy. Tobacco control, 2003, 12(Suppl. 1):i60-70.

3. Johnston LD, O'Malley PM, Bachman JG. Monitoring the future national survey results on drug use, 1975-2002, vol. II. College Students and adults ages 19-40. Bethesda, National Institute on Drug Abuse, 2003 (NIH publication no. 03-5376).

4. Schoenborn CA, Vickerie JL, Barnes PM. Cigarette smoking be havior of adults: United States, 1997-98. Hyattsville, Maryland, National Center for Health Statistics, 2003 (Advance data from Vital and Health Statistics, no. 331).

5. Machuca G et al. Effect of cigarette smoking on periodontal status of healthy young adults. Journal of periodontology, 2000, 71:73-8.

6. Abdullah ASM, Husten CG. Promotion of smoking cessation in developing countries: a framework for urgent public health interventions. Thorax, 2004, 7:623-30.

7. Crofton JW, Fréour PP, Tessier JF. Medical education on tobacco: implications of a worldwide survey. Medical education, 1994, 28:187-96.

8. Crofton JW, Tessier JF. A worldwide survey of knowledge and attitudes of tobacco among medical students. In: Richmond
$\mathrm{R}$, ed. Educating medical students about tobacco: planning and implementation. Paris, International Union against Tuberculosis and Lung Disease, 1997:271-80.

9. Richmond R. Teaching medical students about tobacco. Thorax, 1999, 54:70-8.

10. Zhou L, Huang J, Liu J. Smoking among Shanghai medical students and the need for comprehensive intervention strategies. Health promotion international, 1997, 12:27-32.

11. Richmond RL, Kehoe L. Smoking behavior and attitudes among Australian medical students. Medical education, 1997, 31:169-76.

12. Arnett JJ. Emerging adulthood: A theory of development from the late teens through the twenties. American psychologist, 2000, 55:469-80.

13. Wetter DW et al. Prevalence and predictors of transitions in smoking behavior among college students. Health psychology, 2004, 23:168-77.

14. Controlling the Smoking Epidemic. Report of a World Health Organization Expert Committee on Smoking Control. Geneva, World Health Organization, 1979 (WHO Technical Report Series, No. 636).

15. Gil E et al. Prevalencia del consumo de tabaco en los profesionales sanitarios del Insalud 1998 [Prevalence of smoking among health professionals working in the National Institute of Public 
Health Care (Insalud) 1998]. Prevención del tabaquismo, 2000 2(1):22-31.

16. Richmond R. Teaching medical students about tobacco. Thorax, 1999, 54:70-8.

17. Doyle $\mathrm{D}$ et al. Health professions as research partners in community oriented primary care. Journal of community health, 1998, 23:337-46.

18. Nerín I. Fumando espero [Smoking I await...]. Archivos de bronconeumología, 2000, 36:115-7.

19. Mas A et al. Smoking habits among sixth-year medical students in Spain. Archivos de bronconeumología, 2004, 40(9):403-8.

20. Metintaş $S$ et al. Smoking patterns of university students in Eskişehir, Turkey. Public health, 1998, 112:261-4.

21. Drumaz A, Ustun B. Determination of smoking habits and personality traits among nursing students. Journal of nursing education, 2006, 45(8):328-33.

22. Yazici H, Özbay Y. Üniversite ögrencilerinin sigara içme davranislarinin sigarayi birakma sikligi yeniden beslama nedenleri ve sigara içmeyi birakmaya iliskin öz-yeterlik inançlari açisindan incelenmesi [A study of cigarette smoking habits of university students, the incidence of their giving up the habit, reasons for starting again and its relation to feelings of self-esteem Malatya, Turkey]. Ulusal psikolojik danisma ve rehberlik kongresi, 2003.

23. Patkar AA et al. A comparison of smoking habits among medical and nursing students. Chest, 2003, 124:1415-20.

24. Karaçam Z, Kitis Y, Çetin H. Hacettepe Üniversitesi saglik hizmetleri meslek yüksek okullari ögrencilerinin sigara içme durumu ve sigara iliskin davranislari [Smoking and smokingrelated behavior in students of Hacettepe University health services professional college]. Hemsirelikforumu dergisi, 2002, 5(1):47-5.

25. Haddad LG, Malak MZ. Smoking habits and attitudes towards smoking among university students in Jordan. International journal of nursing studies, 2002, 39:793-802.

26. World Health Organization. Report of country profile of Iran in year 2001 (http://www.emro.who.int/iran/, accessed 17 November 2008).

27. Combating the tobacco epidemic. In: The world health report 1999 - making a difference. Geneva, World Health Organization, 1999:65-70.

28. Seal N. Preventing tobacco and drug use among Thai high school students through life skills training. Nursing and health sciences, 2006, 8:164-8.

29. Wechsler $\mathrm{H}$ et al. Increased levels of cigarette use among college students: A cause for national concern. Journal of the American Medical Association, 1998, 280(19):1673-8.

30. Chen $\mathrm{X}$ et al. Pattern of cigarette smoking among students from 19 college and universities in Jiangsu province, China: a latent class analysis. Drug and alcohol dependence, 2004, 76:153-63.

31. Suzuki K et al. Smoking among Japanese nursing students: Nationwide survey. Journal of advanced nursing, 2005, 49:268-75.

32. Kasatura I. Gençlik ve bagimlilik [Youth and addiction]. Istanbul, Evrim Yayinevi, 1998.

\section{WHO Report on the Global Tobacco Epidemic, 2009: Implementing smoke-free environments}

This report is the second in a series that tracks the status of the tobacco epidemic and the impact of the interventions that are being implemented to stop it. It provides a comprehensive overview of the evidence base for protecting people from the harms of second-hand tobacco smoke through legislation and enforcement. There is a special focus on the status of implementation of smoke-free policies, with detailed data collected for the first time ever on a global basis at both the national level and for large subnational jurisdictions. Additional analyses of smoke-free legislation were performed, allowing a more detailed understanding of progress and future challenges in this area.

The report can be downloaded at: WHO/WHO Report on the Global Tobacco Epidemic, 2009: Implementing smoke-free environments. 